Article

\title{
Logistic Regression Model for Determination of the Age of Brown Hare (Lepus europaeus Pall.) Based on Body Weight
}

\author{
Marian Flis ${ }^{1}$, Piotr Czyżowski ${ }^{1}$, Sławomir Beeger ${ }^{1}$, Bogusław Rataj ${ }^{2}$ and Mirosław Karpiński ${ }^{1, *(1)}$ \\ 1 Department of Animal Ethology and Wildlife Management, University of Life Sciences in Lublin, \\ Akademicka 13, 20-950 Lublin, Poland; marian.flis@up.lublin.pl (M.F.); piotr.czyzowski@up.lublin.pl (P.C.); \\ slawomir.beeger@up.lublin.pl (S.B.) \\ 2 Polish Hunting Association, District Board Nowy Sacz, 33-300 Nowy Sacz, Poland; brataj66@gmail.com \\ * Correspondence: miroslaw.karpinski@up.lublin.pl
}

check for

updates

Citation: Flis, M.; Czyżowski, P.; Beeger, S.; Rataj, B.; Karpiński, M Logistic Regression Model for Determination of the Age of Brown Hare (Lepus europaeus Pall.) Based on Body Weight. Animals 2022, 12, 529. https://doi.org/10.3390/ ani12040529

Academic Editor: Mathew Crowther

Received: 16 December 2021 Accepted: 18 February 2022 Published: 21 February 2022

Publisher's Note: MDPI stays neutral with regard to jurisdictional claims in published maps and institutional affiliations.

Copyright: (C) 2022 by the authors. Licensee MDPI, Basel, Switzerland. This article is an open access article distributed under the terms and conditions of the Creative Commons Attribution (CC BY) license (https:// creativecommons.org/licenses/by/ $4.0 /)$.
Simple Summary: Because the determination of the age of brown hares (Lepus europaeus) is difficult, we developed a method for age determination on the basis of animal body weight. On the basis of the results of postmortem analysis of body weight and eye-lens weight, which provide reliable information on the change in these parameters with age, a logistic regression model was developed to classify brown hares as either juveniles (up to one year old) or adults (more than one year old), with a body weight of $4.227 \mathrm{~kg}$ as the limiting interval. With an accuracy of $95 \%$, this noninvasive method can be used in both scientific research and population management.

\begin{abstract}
We developed an algorithm to classify brown hares into two age classes, juveniles (up to 1 year old) and adults (over 1 year old), based on body weight, which can be determined by both the examination of live animals and postmortem analysis. Considering the strong correlation between lens weight and carcass weight, we assumed that hares could be classified into one of the two age groups based only on carcass weight, using a logistic regression model. Using logistic regression, a model was constructed to assess the age of hares based on their body weight. For comparison with the current age-assessment method based on the dry lens weight, a logistic regression classifying the hares based on the dry lens weight was performed as well. The results of the study facilitated the development of a method to classify hares into age groups based on body weight. The proposed approach is innovative, as it allows for the determination of the age of not only culled (postmortem) but also live hares. The method is easy and does not require laboratory tests; hence, the results can be used immediately following evaluation. This method allows hares to be categorized into two age groups (juveniles and adults). With an accuracy of $97.52 \%$ and $95.45 \%$ in the case of juvenile and adult hares, respectively, the proposed approach can be widely used both in population management and scientific research.
\end{abstract}

Keywords: brown hare; Lepus europaeus; body weight; lens weight; age determination

\section{Introduction}

In the management of hunting practices and the management of wild animal populations, animal welfare must be constantly monitored with simple and widely available ecological indicators. Such indicators should be easy to obtain and use, predictably sensitive and responsive to environmental impacts, and easy to interpret [1-4]. These indicators include parameters of animal condition, e.g., body size and weight, which should be constantly monitored as part of basic hunting management. Body weight, or carcass weight in the case of large game, is an easily accessible indicator of the condition of the population. Body weight also provides important information on the dynamics of changes in individual quality that determines the scope of procedures employed in the hunting management of game populations. In wild animals, body weight and size are directly associated with the 
physiological processes of the organism that significantly influence the individual condition of animals. In turn, the individual condition of game animals reflects the appropriate density in a hunting ground and determines further trends in population management $[5,6]$. As a rule, large and heavy males have preferential access to females and are more often chosen by females for mating. Larger and heavier females are characterized by higher reproductive success, longer lifespan, and earlier breeding, making them more likely to rear offspring [7-9]. This is also observed in other young animals, whose large size and body weight ensure a higher chance of surviving the first winter [10,11]. Larger specimens are also characterized by lower predation-related mortality and lower susceptibility to disease [12].

Animal body weight is mainly determined by body size and accumulated fat stores $[6,13]$. Parameters of body weight and condition are strongly dependent on environmental factors, with climatic conditions, food resources, population density, animal age, and seasonality being the primary determinants [14]. Body weight undergoes seasonal variations and depends on many factors, e.g., physiological states, such as pregnancy or parasite infestation [15-18]. The body weight of hares is also influenced by transformations of ecosystems, such as intensification of agriculture with the establishment of large-scale plantations. This type of simplified farming impairs the heterogeneity of agroecosystems, which provide the basic habitat for hares [19-22]. Given the relationship between environmental factors, body weight, and individual condition, the variability in these indicators can be used as a predictor of individual quality and as an accessible marker of the adaptation of a population to trophic habitat conditions.

Hares are closely related to field ecosystems. Although more than 50 species are known worldwide, only three representatives of the hare family exist in Europe: brown hare (Lepus europaeus), white-tailed hare (Lepus timidus), and wild rabbit (Oryctolagus cuniculus). Among these species, the brown hare is the most important, with a distribution range extending from the Pyrenees to Lake Baikal [23]. In ecological research on hare population management, the age of harvested animals must often be assessed $[24,25]$. The most commonly used method to determine the age of hares is palpation to detect the presence or absence of the Stroh sign (cartilaginous thickening of the ulnar epiphysis). Such an assessment facilitates discrimination between young (up to 1 year old) and adult (more than 1 year old) hares [23,26]. As suggested by Kauhal and Soveri [27], who compared three methods of hare age assessment (palpation, radiographic method, and lens weight), palpation is more useful than the radiographic method. The authors found that determination of eye lens weight and palpation are the most suitable methods of age assessment, yielding similar results.

\section{Aim and Research Hypothesis}

Owing to objective problems associated with field research, quick and precise assessment of the age of hares is difficult in practice. Hence, we developed an algorithm for classification of hares into two age classes: juveniles (up to 1 year old) and adults (more than 1 year old) based on body weight, which can be determined by both examination of live animals and postmortem analysis. Hare age assessment based on lens weight is the most precise method; however, it is difficult to implement on hunting grounds and can only be performed after culling. Therefore, we decided against employing this approach, assuming a strong correlation between eye-lens weight and hare-carcass weight, as demonstrated by Meomartino et al. [28]. Considering this correlation, we assumed that hares can be classified into one of the two age groups based on carcass weight alone and using an appropriate logistic model.

\section{Materials and Methods}

\subsection{Animals and Research Area}

The research involved 297 hares culled in two hunting districts located in Lublin Upland, where the species is still hunted (Figure 1). Both districts are characterized by a 
high density of brown hares, thus making hunting possible without a detrimental effect on the population. The harvesting rate in these districts during the last two hunting seasons was approximately 5 hares per 100 ha area. The research was conducted during group hunting in November and December 2019, in accordance with provisions of Polish hunting laws. Due to the COVID-19 restrictions imposed in 2020, the animals were culled by individual hunters in compliance with the decision of the Minister of Climate and Environment of 15 December 2020 (DLE-ZŁ.4142.1.2020).

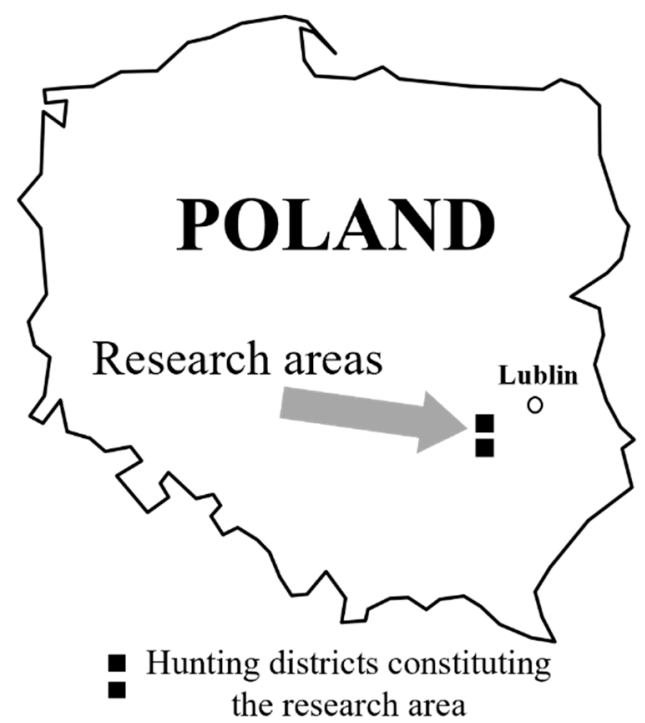

Figure 1. Location of the research area.

\subsection{Methods and Measurements}

The body weight of the animals was measured immediately after culling. The hares were weighed with an accuracy of $0.1 \mathrm{~kg}$ using a Kern HCB20K10 portable balance (Kern \& Sohn, Albstadt, Germany). Age was determined by assessing the presence or absence of the Stroh sign; this allowed for discrimination between juvenile (up to 1 year old) and adult (more than 1 year old) animals. The sex of the animals was determined based on the appearance of secondary sexual characteristics $[23,26]$.

Additionally, the left eyeball was dissected from each individual and preserved in 10\% buffered formalin. The lens was removed from each eyeball in laboratory conditions to determine the age of the hare based on the weight of the dried lens and to verify the results of the field method. The lenses were dried to constant weight in an SML 32 laboratory dryer (Zelmer, Poznań, Poland) at $100{ }^{\circ} \mathrm{C}$ for $24 \mathrm{~h}$ [29]. After drying, the lenses were weighed on an analytical balance (Pioneer OHAUS, Nänikon, Switzerland) with an accuracy of $0.001 \mathrm{~g}$. This method is based on the observation that the eye-lens weight increases relatively intensively during the first year of life, whereas a lower increase is recorded in the following years. In accordance with this principle and based on the data obtained in the study, the animals were categorized as juveniles or adults, with an eye-lens-weight cutoff value of $290 \mathrm{mg}$ [29-33].

\section{Analysis}

The hares were divided into two age groups according to the carcass weight of individual animals. Due to the lack of sexual dimorphism in terms of body weight of females and males, the animals were not grouped according to sex. Body weight and dry lens weight were analyzed in the separate age groups in terms of the following characteristics: mean value, standard deviation, minimum, and maximum. We assessed the strength of the relationships between the examined variables, using the Pearson correlation coefficient; the results are illustrated in a scatterplot with a fitted regression line. 
Using logistic regression, a model was constructed to assess the age of hares based on body weight. For comparison with the current age-assessment method, a logistic regression was also performed to classify the hares based on dry lens weight.

\section{Results}

Body weight and dry lens weight were analyzed separately in the two age groups. Body weight ranged from 3.3 to $4.4 \mathrm{~kg}$ in the juvenile group and from 4.0 to $5.5 \mathrm{~kg}$ in the adult group. The mean value of this parameter was $3.95 \mathrm{~kg}$ in the juvenile group and $4.56 \mathrm{~kg}$ in the adult group, with similarly low standard deviations of 0.23 and $0.26 \mathrm{~kg}$, respectively (Table 1 ).

Table 1. Body weight and dry lens weight in the two age groups.

\begin{tabular}{ccccc}
\hline \multirow{2}{*}{ Item } & \multicolumn{2}{c}{ Age } & \multirow{2}{*}{ Mean } & $\boldsymbol{p}$-Value \\
\cline { 2 - 3 } & Juveniles $(\boldsymbol{n = 1 2 1})$ & Adults $(\boldsymbol{n = 1 7 6 )}$ & & 0.023 \\
\hline Body weight, $\mathrm{kg}$ & $3.95 \pm 0.23$ & $4.56 \pm 0.26$ & $4.31 \pm 0.39$ & 0.012 \\
\hline Dry lens weight, $\mathrm{kg}$ & $0.25 \pm 0.03$ & $0.38 \pm 0.06$ & $0.33 \pm 0.08$ & 0.03 \\
\hline
\end{tabular}

The dry lens weight ranged from 0.17 to $0.40 \mathrm{~g}$ in the juvenile group and from $0.22 \mathrm{~g}$ to $0.56 \mathrm{~g}$ in the adult group. The mean dry lens weight in the juvenile group was $0.25 \mathrm{~g}$, with a standard deviation of $0.03 \mathrm{~g}$. The mean dry lens weight in the adult group was $0.38 \mathrm{~g}$, with a standard deviation of $0.06 \mathrm{~g}$ (Table 1 ).

Next, the Pearson correlation coefficient was calculated, and a very strong positive correlation was found between body weight and dry lens weight (Pearson correlation coefficient $r=0.75, p<0.001$ ) (Figure 2). Such a strong correlation suggests that the age of hares can be determined based not only on dry lens weight but also body weight. A model was generated by using logistic regression to estimate the age of hares based on body weight.

$$
P(Y=A \mid \text { WEIGHT })=\frac{e^{-70.1836+16.6019 \cdot \text { WEIGHT }}}{1+e^{-70.1836+16.6019 \cdot W E I G H T}}
$$

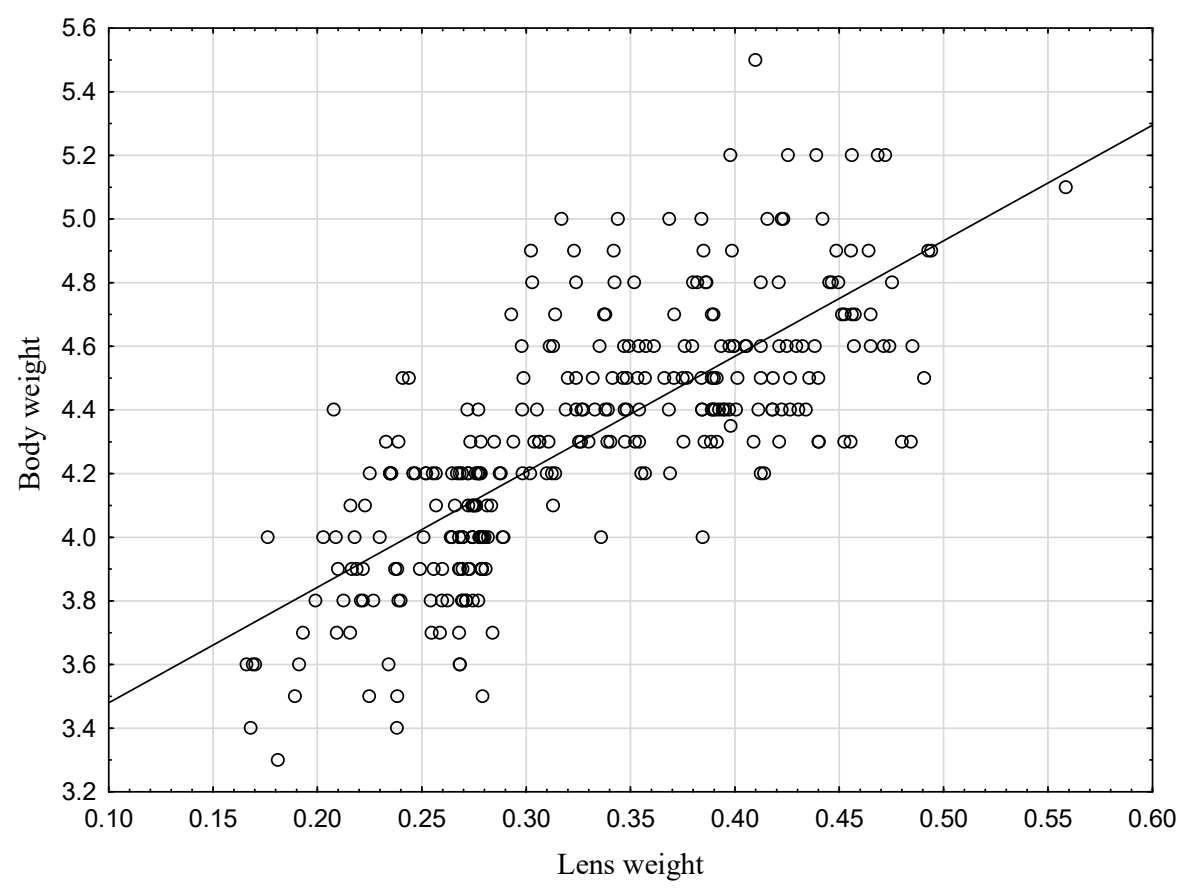

Figure 2. Scatterplot of body weight and dry lens weight with a fitted regression line. 
This relationship expresses the probability of classification of an individual into group A (adult hares) based on body weight. If the probability is at least 0.5 , the model classifies such an individual as an adult animal (A); otherwise, the animal is assigned to the juvenile group $(\mathrm{J})$. The logit function plot is presented in Figure 3, and the model parameters are shown in Table 2.

Model: Logistic Regr.

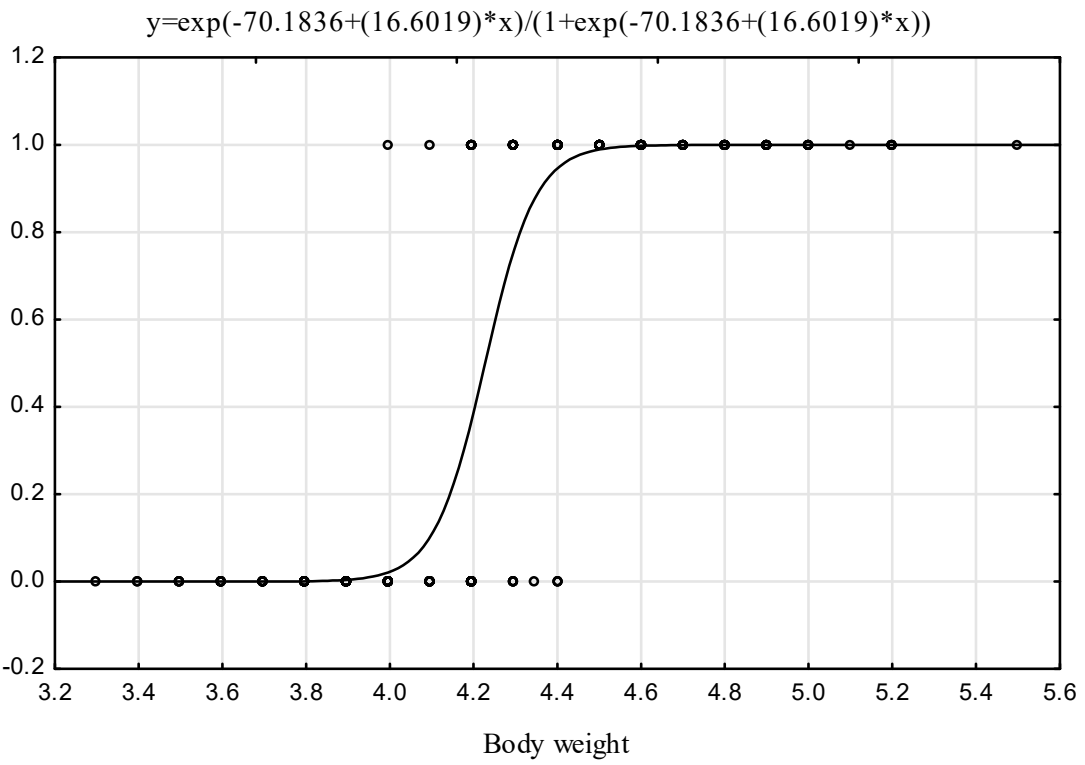

Figure 3. Fitted logit function and observed values $(1=\mathrm{A}, 0=\mathrm{J})$.

Table 2. Parameter evaluation in the logistic regression model in relation to body weight.

\begin{tabular}{ccc}
\hline \multirow{2}{*}{$N=\mathbf{2 9 7}$} & Total Loss: $\mathbf{5 5 . 7 1 2 8} \mathbf{C h i}^{\mathbf{2}} \mathbf{( 1 )}=\mathbf{2 9 0 . 0 6} \boldsymbol{p = \mathbf { 0 0 0 0 }}$; Modeled $\boldsymbol{p}$, Age $=\mathbf{A}$ \\
\cline { 2 - 3 } & Constant B0 & Body Weight \\
\hline Estimation & -70.1836 & 16.6019 \\
\hline Standard error & 11.3284 & 2.6707 \\
\hline $\mathrm{t}(295)$ & -6.1953 & 6.2164 \\
\hline$p$ & 0.000000002 & 0.000000002 \\
\hline
\end{tabular}

This model correctly classified $92.59 \%$ of the hares into the two age groups according to their body weight, with $93.39 \%$ and $92.05 \%$ accuracy for juveniles (J) and adults (A), respectively (Table 3 ). The odds ratio of correct classifications to the adult group based on body weight was 163 times larger than that of incorrect classifications.

Table 3. Classification of cases in the logistic model in relation to body weight.

\begin{tabular}{cccc}
\hline \multirow{2}{*}{ Observed } & \multicolumn{3}{c}{ Classification of Cases; Odds: $\mathbf{1 6 3 . 4 5 ;}$ \% Correctness: $\mathbf{9 2 . 5 9 \%}$} \\
\cline { 2 - 4 } & Predicted (J) & Predicted (A) & Percent Correctness \\
\hline Juveniles & 113 & 8 & 93.39 \\
\hline Adults & 14 & 162 & 92.05 \\
\hline
\end{tabular}

The presented model classifies hares into the adult group when their body weight exceeds $4.227 \mathrm{~kg}$ (Figure 4). To compare the proposed body-weight-based model of age classification with the current method based on the dry lens weight, a logistic model was generated.

$$
P(Y=A \mid L E N S)=\frac{e^{-20.2314+68.2144 \cdot L E N S}}{1+e^{-20.2314+68.2144 \cdot L E N S}}
$$


Model: Logistic Regr.

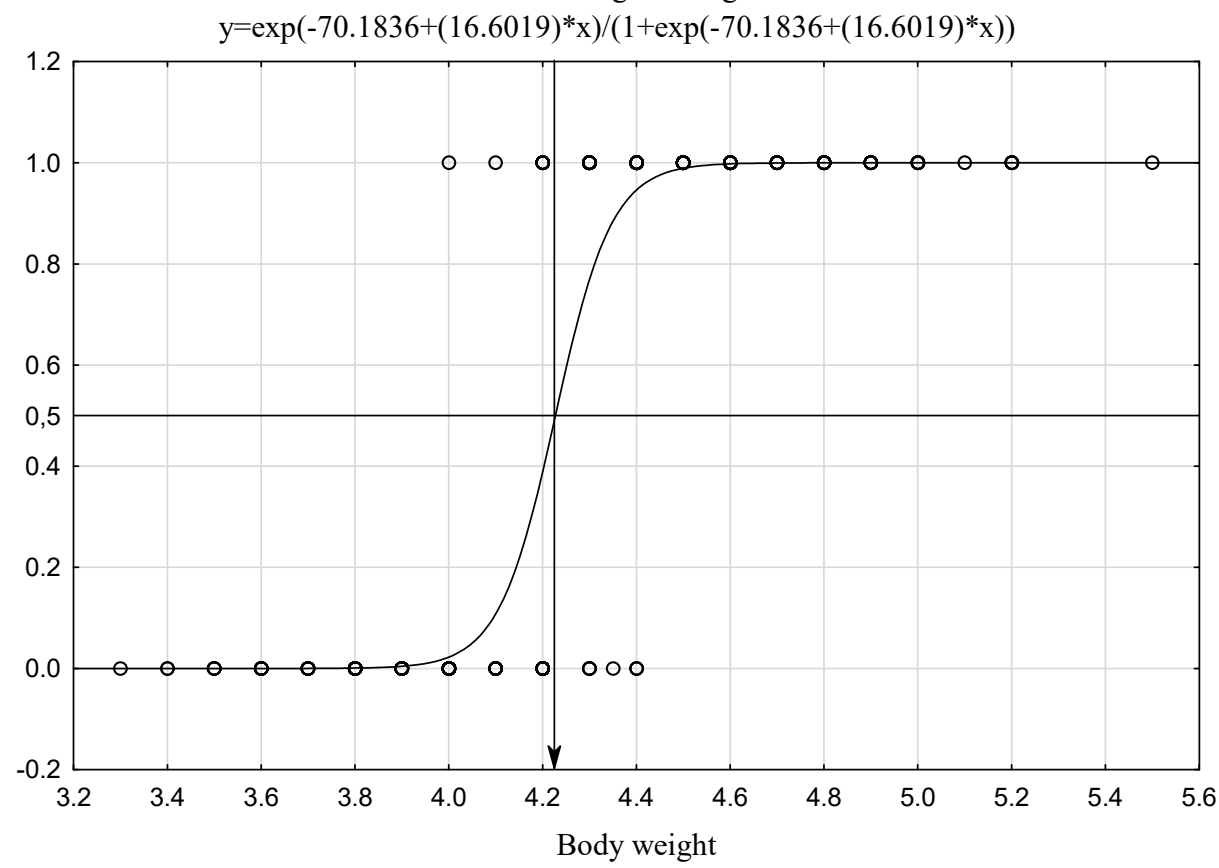

Figure 4. Cutoff point for classification of cases based on body weight $(1=\mathrm{A}, 0=\mathrm{J})$.

The logit function plot is presented in Figure 5, and the model parameters are shown in Table 4.

Model: Logistic Regr.

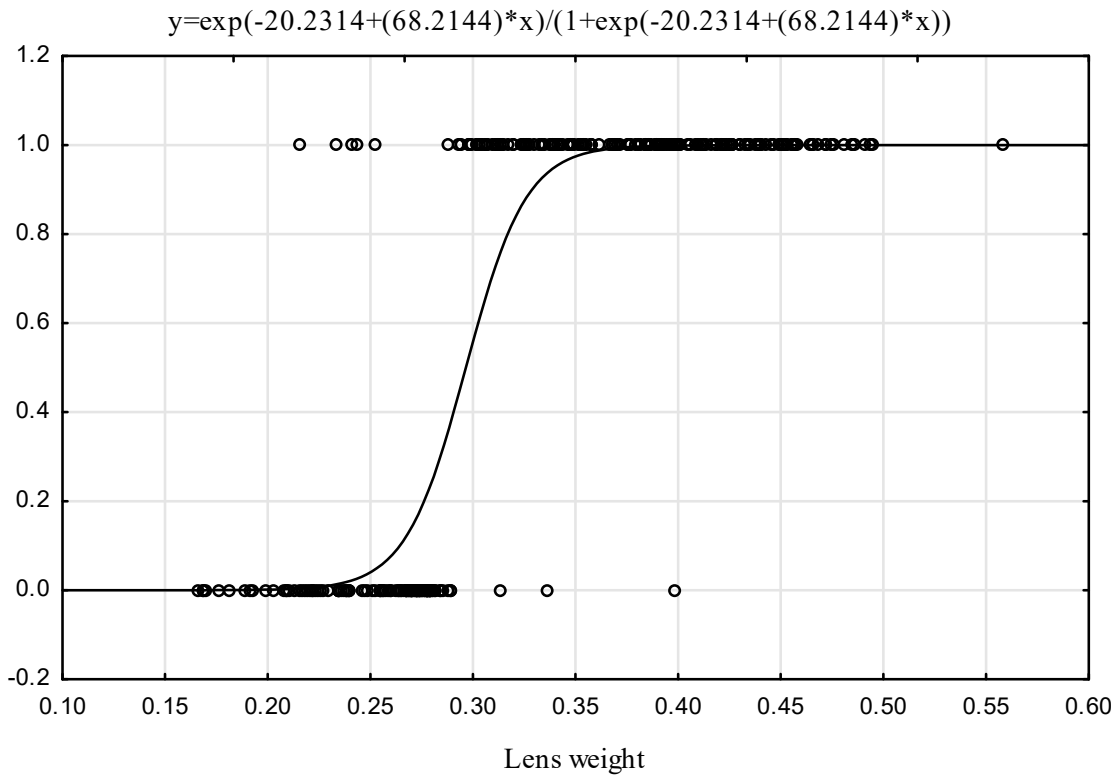

Figure 5. Fitted logit function and observed values $(1=\mathrm{A}, 0=\mathrm{J})$. 
Table 4. Parameter evaluation in the logistic regression model in relation to dry lens weight.

\begin{tabular}{|c|c|c|}
\hline \multirow{2}{*}{$N=297$} & \multicolumn{2}{|c|}{ Total Loss: $59.7183 \mathrm{Chi}^{2}(1)=282.05 p=0.0000$, Modeled $p$, Age $=\mathrm{A}$} \\
\hline & Constant B0 & Lens Weight \\
\hline Estimation & -20.2314 & 68.2144 \\
\hline Standard error & 2.7437 & 9.4179 \\
\hline$t(295)$ & -7.3738 & 7.2431 \\
\hline$p$ & 0.000000000002 & 0.000000000004 \\
\hline
\end{tabular}

This model correctly classified $96.30 \%$ of the hares into two age groups according to their lens weight, including $97.52 \%$ of the juvenile hares $(\mathrm{J})$ and $95.45 \%$ of the adult hares (A) (Table 5).

Table 5. Classification of cases in the logistic model in relation to dry lens weight.

\begin{tabular}{cccc}
\hline & \multicolumn{2}{c}{ Classification of Cases; Odds: 826.00; \% Correct: $\mathbf{9 6 . 3 0 \%}$} \\
\cline { 2 - 3 } Observed & Predicted & Predicted & \multirow{2}{*}{ Percent Correctness } \\
\cline { 2 - 3 } & $\mathbf{J}$ & $\mathbf{A}$ & 97.52 \\
\hline Juveniles & 118 & 3 & 95.45 \\
\hline Adults & 8 & 168 &
\end{tabular}

The generated model classifies hares into the adult group when their dry lens weight exceeds $0.297 \mathrm{~kg}$ (Figure 6). These results are consistent with those obtained by the lensweight-based age assessment model reported by Pintur [34]. The two models achieved a similar percentage of correct classifications, which indicates the potential of our alternative hare age-assessment model based on body weight.

Model: Logistic Regr.

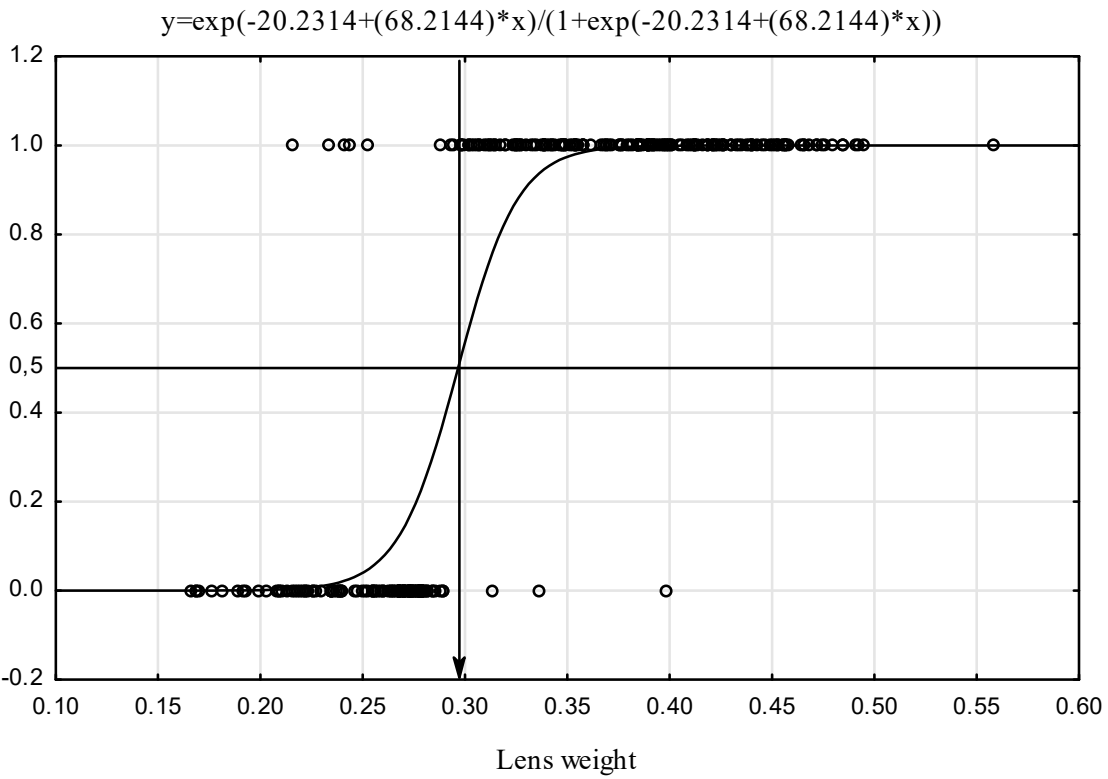

Figure 6. Cutoff point for classification of cases based on dry lens weight $(1=\mathrm{A}, 0=\mathrm{J})$.

\section{Discussion}

To identify population trends in wild animals, many parameters must be determined, with the age of individual animals being one of the most important factors. Knowing the age of individual animals allows for population prediction in ecosystems exposed 
to environmental factors. Determining the age of hares is a complicated task. The Stroh method has been used for many years both in population management and scientific research. It consists of palpation-based examination of cartilage thickening on the outer side of the ulna at a distance of approximately $1 \mathrm{~cm}$ from the wrist joint. Since the thickening disappears at the age of $8-9$ months, this method allows for discrimination between juvenile and adult (more than 1 year old) animals [26,35]. However, the results of this method do not facilitate precise determination of age. An advantage of this approach is the possibility of examining live animals; a drawback is that it requires considerable experience in determining the presence or absence of the Stroh sign.

In scientific research, the age of animals is often assessed based on dry lens weight. Laboratory weighing of lenses can help to discriminate between juvenile (up to 1 year old) and adult (more than 1 year old) individuals [22,29-33]. Since the lens weight gain in the first year of life is more intense, the weight data indicate the time of birth [36]. In older individuals, lens weight gain is much slower, although it is possible to estimate the age of animals and distinguish the subsequent years of life in individuals more than 1 year old $[29,31,34]$. Despite its accuracy, the main drawback of this method is that assessment can only be performed on culled hares (postmortem). Therefore, we constructed a body-weightbased age-assessment method as an alternative approach. The results of the present research facilitated generation of a logistic model, which showed $93.39 \%$ and $92.05 \%$ accuracy in the age assessment in juvenile and adult hares, respectively. The key advantages of the proposed method are its simplicity; the possibility of assessing live animals with minimized invasiveness, even in comparison with the Stroh method; and its high efficiency.

\section{Conclusions}

The results of the present study facilitated the development of an age-classification method for hares based on body weight. The proposed approach is innovative, as it allows for determination of the age of not only culled (postmortem) but also live hares. The method is easy and does not require laboratory tests; hence, the results can be used immediately following evaluation. This method allows for hares to be assigned to one of two age groups (juveniles and adults). The developed logistic regression model produced a body-weight cutoff value of $4.227 \mathrm{~kg}$. The estimated accuracy of the model is $97.52 \%$ and $95.45 \%$ for juvenile and adult hares, respectively. Such high accuracy indicates that the proposed approach can be widely used both in population management and scientific research. However, even in the European region, depending on latitude, hare size and, thus, body weight, vary. Therefore, in the case of hares from the southern and northern ends of the continent, the model should be verified. Nevertheless, the proposed method can achieve similar accuracy when adjusted for varying body-weight distributions.

Author Contributions: M.F., conceptualization, methodology, validation, investigation, formal analysis, and project administration; P.C., conceptualization, methodology, investigation, and writingreview and editing; S.B., investigation, writing-original draft preparation, and writing-review and editing; B.R., investigation; M.K., conceptualization, methodology, validation, investigation, formal analysis, and project administration. All authors have read and agreed to the published version of the manuscript.

Funding: This research received no external funding. 
Institutional Review Board Statement: The study material included hares culled during collective hunting by Polish hunters. In accordance with the Polish law, hares can only be hunted in collective hunting in the period from 1 November to 31 December. After each driving round during the hunt, the dead hares were weighed and their eyeball was dissected for laboratory analysis. In the 2019/1920 hunting season, the material was obtained from 190 culled hares. Due to restrictions related to the occurrence of COVID-19, collective hunting was banned in the hunting season 2020/2021 (restrictions in Poland due to the pandemic). Thus, individual hunting was the only solution. Therefore, the Minister of Climate and Environment was requested for consent on the use of an alternative culling method by hunters in individual hunting. Such consent was obtained by virtue of the decision of the Minister of Climate and Environment of 15 December 2020 (DLŁ-ZŁ.4142.1.2020). On the basis of this decision, the hunters culled 107 hares in individual hunts. During hunting, dead hares were weighed and their eyeballs were dissected for laboratory analyses. Since the entire study and sampling were performed on dead animals culled in accordance with the provisions of the hunting law in Poland, such research did not require the consent of the Ethics Committee.

Informed Consent Statement: Not applicable.

Data Availability Statement: The data presented in this study are available upon request from the corresponding author.

Conflicts of Interest: The authors declare no conflict of interest.

\section{References}

1. Dale, V.H.; Beyeler, S.C. Challenges in the development and use of ecological indicators. Ecol. Indic. 2001, 1, 3-10. [CrossRef]

2. Mac Nally, R. Multiple regression and inference in ecology and conservation biology: Further comments on identifying important predictor variables. Biodivers. Conserv. 2002, 11, 1397-1401. [CrossRef]

3. Zannèse, A.; Morellet, N.; Targhetta, C.; Coulon, A.; Fuser, S.; Hewison, A.J.; Ramanzin, M. Spatial structure of roe deer populations: Towards defining management units at a landscape scale. J. Appl. Ecol. 2006, 43, 1087-1097. [CrossRef]

4. Morellet, N.; Gaillard, J.; Hewison, A.M.; Ballon, P.; Boscardin, Y.; Duncan, P.; Klein, F.; Maillard, D. Indicators of ecological change: New tools for managing populations of large herbivores. J. Appl. Ecol. 2007, 44, 634-643. [CrossRef]

5. Bonino, N.; Bustos, J.C. Kidney mass and kidney fat index in the European Hare inhabiting northwestern Patagonia. Mastozool. Neotrop. 1998, 5, 81-85.

6. Fernández, A.; Soriguer, R.; Carro, F.; Castién, E. Relation between physical condition and reproductive activity in a population of Iberian hares, Lepus granatensis in northern Iberian Peninsula. J. Vertebr. Biol. 2010, 59, 1-8. [CrossRef]

7. Iason, G.R. The effects of size, age and a cost of early breeding on reproduction in female mountain hares. Ecography 1990, 13, 81-89. [CrossRef]

8. Sheriff, M.J.; Krebs, C.J.; Boonstra, R. The sensitive hare: Sublethal effects of predator stress on reproduction in snowshoe hares. J. Anim. Ecol. 2009, 78, 1249-1258. [CrossRef] [PubMed]

9. Rödel, H.G.; Valencak, T.G.; Handrek, A.; Monclús, R. Paying the energetic costs of reproduction: Reliance on postpartum foraging and stored reserves. Behav. Ecol. 2016, 27, 748-756. [CrossRef]

10. O'Donoghue, M. Early survival of juvenile snowshoe hares. Ecology 1994, 75, 1582-1592. [CrossRef]

11. Schai-Braun, S.C.; Steiger, P.; Ruf, T.; Arnold, W.; Hackländer, K. Maternal effects on reproduction in the precocial European hare (Lepus europaeus). PLoS ONE 2021, 16, e0247174. [CrossRef] [PubMed]

12. Murray, D.L. Differential body condition and vulnerability to predation in snowshoe hares. J. Anim. Ecol. 2002, 71, 614-625. [CrossRef]

13. Hackländer, K.; Tataruch, F.; Ruf, T. The effect of dietary fat content on lactation energetics in the European hare (Lepus europaeus). Physiol. Biochem. Zool. 2002, 75, 19-28. [CrossRef]

14. Gigliotti, L.C.; Berg, N.D.; Boonstra, R.; Cleveland, S.M.; Diefenbach, D.R.; Gese, E.M.; Jacob, S.I.; Kielland, K.; Krebs, C.J.; Kumar, A.V.; et al. Latitudinal variation in snowshoe hare (Lepus americanus) body mass: A test of Bergmann's rule. Can. J. Zool. 2020, 98, 88-95. [CrossRef]

15. Newey, S.; Thirgood, S. Parasite-mediated reduction in fecundity of mountain hares. Proc. R. Soc. Lond. Biol. Sci. Ser. B 2004, 271, 413-415. [CrossRef] [PubMed]

16. Lello, J.; Boag, B.; Hudson, P.J. The effect of single and concomitant pathogen infections on condition and fecundity of the wild rabbit (Oryctolagus cuniculus). Int. J. Parasitol. 2005, 35, 1509-1515. [CrossRef] [PubMed]

17. Alzaga, V.; Tizzani, P.; Acevedo, P.; Ruiz-Fons, F.; Vicente, J.; Gortázar, C. Deviance partitioning of host factors affecting parasitization in the European brown hare (Lepus europaeus). Naturwissenschaften 2009, 96, 1157-1168. [CrossRef] [PubMed]

18. Flis, M.; Rataj, B.; Grela, E.R. Occurrence of Cephenemyia stimulator larvae in male roe deer (Capreolus capreolus L.) in the Lublin Upland, Poland, and their impact on particular animal health indicators. J. Vet. Res. 2021, 65, 287-292. [CrossRef] [PubMed]

19. Smith, R.K.; Jennings, N.V.; Robinson, A.; Harris, S. Conservation of European hares Lepus europaeus in Britain: Is increasing habitat heterogeneity in farmland the answer? J. Appl. Ecol. 2004, 41, 1092-1102. [CrossRef] 
20. Berg, N.D.; Gese, E.M.; Squires, J.R.; Aubry, L.M. Influence of forest structure on the abundance of snowshoe hares in western Wyoming. J. Wildl. Manag. 2012, 76, 1480-1488. [CrossRef]

21. Kamieniarz, P.; Voigt, U.; Panek, M.; Strauss, E.; Niewęgłowski, H. The effect of landscape structure on the distribution of brown hare Lepus europaeus in farmlands of Germany and Poland. Acta Theriol. 2013, 58, 39-46. [CrossRef] [PubMed]

22. Flis, M.; Rataj, B. Characteristics of population indicators of brown hare (Lepus europaeus Pall.) obtained during group hunting in the region with the highest density in western part of the Lublin Region in Poland. Appl. Ecol. Environ. Res. 2019, 17, 13701-13711. [CrossRef]

23. Pielowski, Z. Zając. Monografia Przyrodniczo-Łowiecka; PWRiL: Warszawa, Poland, 1979.

24. Bray, Y.; Champely, S.; Soyez, D. Age determination in leverets of European hare Lepus europaeus based on body measurements. Wildl. Biol. 2002, 8, 31-39. [CrossRef]

25. Mallia, E.; Rugge, C.; Cosentino, C.; Gambacorta, E.; Trocchi, V.; Freschi, P. Postnatal growth of Brown hare (Lepus europaeus) in a South Italy rearing centre. Ital. J. Anim. Sci. 2009, 8, 790-792. [CrossRef]

26. Strőh, G. Zwei sichere Altersmerkmale beim Hasen. Berliner. Tierärztl. Wschr. 1931, 47, 180-181.

27. Kauhala, K.; Soveri, T. An evaluation of methods for distinguishing between juvenile and adult mountain hares Lepus timidus. Wildl. Biol. 2001, 7, 295-300. [CrossRef]

28. Meomartino, L.; Pasolini, M.P.; Lamagna, B.; Mennonna, G.; Auletta, L.; Murino, C.; Valle, G.D.; Esposito, L. Ocular ultrasonographic and biometric features of European brown hares (Lepus europaeus). Anat. Histol. Embryol. 2018, 47, 250-253. [CrossRef]

29. Méres, J.; Ostrihoň, M.; Slamečka, M.; Kaštier, J. Population structure of brown hare (Lepus europaeus): A case study in selected areas of Nitra region. Acta Facult. Forest. Zvol. 2013, 1, 43-58.

30. Caboń-Raczyńska, K.; Raczyński, J. Method of determination of age in the European hare. Acta Theriol. 1972, 17, 75-86. [CrossRef]

31. Pintur, K.; Popović, N.; Alegro, A.; Severin, K.; Slavica, A.; Kolić, E. Selected indicators of brown hare (Lepus europaeus Pallas, 1778) population dynamics in northwestern Croatia. Vet. Arh. 2006, 76, 199-209.

32. Suchentrunck, F.; Willing, R.; Hartl, G.B. On eye lens weights and other age criteria of the Brown hare (Lepus europaeus Pallas, 1778). Zeitschr. Säuget. 1991, 56, 365-374.

33. Hruška, J.; Matoušková, J.; Ernst, M.; Slamečka, J. Populační dynamika zajíce polního v letech 2008-2010 na základe stanovení hmotnosti očných čoček (Population dynamics of hares in the years 2008-2010 based on the determination of the weight of eye lenses-in Czech). In Zajac Pol'ný Pred Štvrt'storočím a Dnes; CVŽV Nitra: Nitra, Slovakia, 2011.

34. Misiorowska, M.; Ludwisiak, Ł.; Nasiadka, P. Population parameters of brown hare (Lepus europaeus L.) in regions of the species highest density in Poland. Sylwan 2014, 158, 901-910. [CrossRef]

35. Pielowski, Z.; Raczyński, J. Ecological conditions and rational management of populations. In Ecology and Management of European Hare Populations; PWRiL: Warszawa, Poland, 1976; pp. 269-286.

36. Pegel, M. Der Feldhase (Lepus europaeus Pallas) im Beziehungsgefüge Seiner Um-und Mitweltfaktoren; Ferdinand Enke Verlag: Stuttgart, Germany, 1986. 